\title{
銅損と鉄損を考慮した集中巻永久磁石モ一夕の出力評価
}

\author{
正 員 大西 和 夫（日本サーボ）
}

\section{Output Evaluation of Non-Lap Winding Permanent Magnet Motors Based on Copper and Iron Losses}

\author{
Kazuo Ohnishi ( Japan Servo Co., Ltd. )
}

\begin{abstract}
In this paper, an evaluation factor of permanent magnet motors is enhanced by accounting effects of copper and iron losses as well. A new evaluation factor $k_{M}$ is obtained by the product of an old motor constant $k_{M C}$ and a modification factor $k_{a}$ which is calculated from iron loss ratio.

Next, the evaluation method is applied to permanent magnet motors with non-lap concentric windings. The results show that an improvement by increase of magnetic flux is reduced under consideration of iron losses and the evaluation factor $k_{M}$ is rapidly saturated over 0.7 tesla in air-gap magnetic induction.
\end{abstract}

キーワード：永久磁石モータ, 出カトルク評価, 非ラップ集中巻, 鉄損, 銅損 ( permanent magnet motor, output torque evaluation, non-lap concentric winding, iron loss, copper loss)

\section{1. まえがき}

近年, 永久磁石材料と半導体技術の進歩とも相俟って, 永久磁石モータが各分野に広く使用されている。この種の 小形モー夕は, コストと応用上の要求もあって, 大形モ一 夕とは異なった各種の構造が開発されており，最適な形に 納まっているとは言いがたい。そこで, モータを使う立場 でも，また作る立場でも各種のモ一夕構造の優劣を評価す るための基準または指標が要求されている。

筆者は, 先に永久磁石モータの出力トルクに関する評価 指標の一般式を導いて各種構造の得失を論じ, 特に小形機 で多用されている非ラップ集中巻固定子を対象にしてトル クを最大にする諸元の決定法について検討した(1)。そこ では，小形モー夕の損失の大半を占める銅損だけを取りあ げて考察したが, 高速または高周波で動作する場合には鉄 損が大きくなり，その影響を無視できない。

そこで, 今回銅損に加えて鉄損の影響を考慮した出力評 価を試みた。なお，他の損失として機械損も考えられるが, これはモー夕特性を左右する設計諸元とはあまり関保しな いので，比較評侕する立場からみると省略しても差し支え ないと考えられる。鉄損は，鉄心材料や使用する条件によ つて大きく変化するので，これらを直接対象にして考察す ることも可能であるが, ここでは前論文の考え方を踏裝し， 銅損のみを考慮した評価指標を鉄損の占める割合の装化に よって修正する手法を採用した。この結果, 一応所期の目 的を達成することができたので，概要を報告する。なお，
具体的な計算による検討は，前回と同じ非ラップ集中巻構 造の表面磁石形モー夕を対象にして行った。

\section{2. モー夕楧造と基本式の誘道}

〈2 1〉発生トルク永久磁石が主役になるモ一タと して, 同期モータ, DCブラシ付モータ，DCブラシレス モータおよびステッピングモータなどが挙げられる。これ らの機種は通電制御の方法によって機種が分かれるが, 原 理上すべて同期モー タに属していると考 えられるので,ここ では一般性を持たせ るために图1に示す ような同期モータに ついて考察を進める ことにする。

また簡単のため, 磁束は次式のように 正弦波的にコイルに

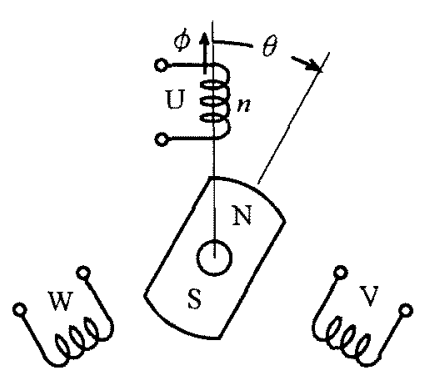

図 1 永久磁石モー夕の基本構成

Fig. 1. Basic Structure of Permanent Magnet Motor 鎖交するものとする。

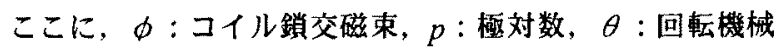
角である。

$$
\phi=\Phi \cos p \theta
$$

発生トルクには，電流と磁石磁界によって発生するトル ク(電磁トルク)のほに, 磁石のみによるコギングトルク 
上電流のみによるレラクタンストルクが存在するが, 通常 の表面磁石構造においては後の二つは比較的小さい。従っ て、ここではこれらを無視することにする。また各巻線に

は, 角周波数 $\omega_{l}$, 実効值 $I_{e}$ の平衡 3 相交流が流れるとする

と，最大発生トルク $T_{M}$ は次式で表される。

$$
\begin{aligned}
& T_{M}=k_{T} I_{e} \\
& k_{T}=m n p \Phi / \sqrt{2}
\end{aligned}
$$

なお, $k_{T}$ : トルク定数, $m:$ 相数, $n:$ 相巻線数である。

〈2 2〉鉄損を考虑した場合の評洒指摆前の論文 (1)ではトルクに比例する評価指標として次に示すモータ コンスタントを導いた。

$$
k_{M C}=\frac{T_{M}}{\sqrt{W_{C}}}=\frac{k_{T}}{\sqrt{m R_{1}}}
$$

なお、この場合は銅損しか考慮していないため, 前論文の 記号 $k_{M}$ の代わりに $k_{M C}$ を用いて区別した。

この導出は本論文の考え方のべースになるため，以下に その骨子を示す。銅損 $W_{C}$ は次式で表される。

$$
W_{C}=m R_{1} I_{e}^{2}
$$

また, 1 相分の抵抗 $R_{1}$ はスロットの総断面積を $S_{T}$, 占積 率 $f_{s}$, 単位コイルの平均長 $l_{1}$, 導体の固有抵抗 $\rho$ として,

$$
R_{1}=\frac{2 m n^{2} \rho l_{1}}{f_{S} S_{T}}
$$

上記 $k_{T}, R_{1}$ を(4) 式に代入することによって，トルクの 評価指標であるモータコンスタントを求めることができる。

$$
k_{M C}=\frac{p \Phi}{2} \sqrt{\frac{f_{S} S_{T}}{\rho l_{1}}}
$$

そこで本論文の主題に移る。銅損に加えて鉄損を考慮に 入れると，全損失は銅損 $W_{C}$ と鉄損 $W_{I}$ の和になる。

$$
W=W_{C}+W_{I}
$$

ここでは，銅損 $W_{C}$ の代わりに全損失 $W$ を用いて (4) 式 を拡張して，次式で新しい詳価指標 $k_{M}$ を定義する。

$$
k_{M}=\frac{T}{\sqrt{W}}
$$

なお，Tは負荷に供給する出力トルクである。

(9) 式を書き換えると

$$
T=k_{M} \sqrt{W}
$$

となり，放熱条件が等しく許容損失が一定とみなされる同 一構造の場合には, 許容トルクは評価指標 $k_{M} に$ 比例する。

〈23〉鉄賣の処理法次に, 問題の鉄損を表すモデ ル式について考察する。鉄損は，通常ヒステリシス損と渦 電流損に分けて次式のように表される(2)。

$$
W_{I}=\left(k_{H} f_{I} B_{I}{ }^{a}+k_{E} f_{I}^{2} B_{I}{ }^{2}\right) V_{I}
$$

ここに, $a, k_{H}, k_{E}$ は定数， $B_{V}, f_{I}$ は鉄心中の磁束の密度 亡周波数, $V_{I}$ は鉄心の重量である。 $a$ の值は, 従来 1.6 も
用いられるが，実用範用の比較的大きい磁束密度では，2.0 が適当之言われるので ${ }^{(3)}$ ，ここでは後者を採用する。こ の他，鉄損は回転磁界や機械的歪みの影響を受けるが，こ こでは計算を簡単にするために大筋をはずれない形にとと゚ め, 次式で計算できるものと仮定する。

$$
W_{I}=k_{I} B_{I}^{2} \omega_{I}^{b} V_{I}
$$

ここに， $k, b$ は鉄心材料によって定まる定数である。 この式は，(11) 式のヒステリシス損と滑電流損を併合した 形になっているので， $b$ は 1.0 と 2.0 の間の数值である。 角周波数 $\omega_{I}$ は, モ一タの回転角速度を $\omega$ として次式で与え られる。

$$
\omega_{I}=p \omega
$$

同期モー夕においては，鉄損は主としてモ一夕の回転に 伴う磁束の変化によって生じるので, 発生したトルクが鉄 損のエネルギーと外部負荷の駆動との両方に消費されると 考えることができる。すなわち，全発生トルク $T_{M}$ は負荷 トルク $T$ と鉄損トルク $T_{I}$ の和になる。

$$
T_{M}=T+T_{I}
$$

鉄損に対応するトルク $T_{I}$ は次式で求められる。

$$
T_{I}=W_{I} / \omega=k_{I} B_{I}^{2} p^{b} \omega^{b-1} V_{I}
$$

電流は,これをトルク定数で割って計算すればよい。

$$
I_{e}=T_{M} / k_{T}
$$

以上の関係式から $T$ と $W$ を計算して (9) 式に入れること によって，評価指標 $k_{M}$ を求めることができる。

\section{3、鉄損を考慮した場合の評価指標の計算}

〈3. 1〉鉄損モデル定数鉄損を(12) 式で近似する場 合，定数 $k_{1} ， b$ を決定しなければならない。モー夕に使用 可能な無方向性珃素鋼板数種類（厚さ $0.35,0.5 \mathrm{~mm}$ )につ いてメーカの鉄損曲線資料より計算した結果， $b$ は 1.36 〜 1.53 の間であった。そこで, 平均的な值しして $b=1.45$ を採用した。 $k_{I}$ は鉄板のグレードに比例して大きく変化す るので，ここでは相対的な值として処理することにする。

〈3.2〉鉄賣算入の方法計算では特定材料の定数を 使用することも可能であるが，一般性を保つ意味から，基 準条件において特定の割合になるように設定した鉄損を持 つ材料を使用するものとして評価指標 $k_{M}$ を求めることに する。

まず，基準条件における鉄損 $W_{I}$ が全損失に占める割合 を $\alpha$ とする。

$$
W_{I}=\alpha W
$$

ここでは，全損失 $W$ が許容される一定值という前提のも とに議論を進めているので，許容される銅損は次式となる。

$$
W_{C}=(1-\alpha) W=\frac{1-\alpha}{\alpha} W_{l}
$$

また，鉄損トルク $T_{I}$ の出カトルク $T$ に対する割合を $\beta$ と する。なお，この $\beta$ は後で (29) 式により決定される。 


$$
T_{I}=\beta T
$$

次に，(5) 式に上記関係式を入れると，次式が成立する。

$$
(1-\alpha) W=m R_{1}\left(\frac{T+\beta T}{k_{T}}\right)^{2}
$$

これより $T$ を解くと, 次式が導かれる。

$$
T=k_{M C} \frac{\sqrt{1-\alpha}}{1+\beta} \sqrt{W}
$$

(10) 式と比輘して, 評伍指標 $k_{M}$ は次のようになる。

$$
\begin{aligned}
& k_{M}=k_{a} k_{M C} \\
& k_{a}=\frac{\sqrt{1-\alpha}}{1+\beta}
\end{aligned}
$$

これより，評伍指標 $k_{M}$ は，鉄損を考慮しない場合の $k_{M C}$ に 係数 $k_{a}$ を乗ずればよいというシンプルな関係式となる。

ここで， $\alpha$ は $W$ が一定のため (12) 式で計算した鉄損値 の変化の割合になる。いま, 対象とする鉄損の基準鉄損 $W_{10}$ に対する比を $\gamma$ とすると， $\alpha$ は次式のようになる。

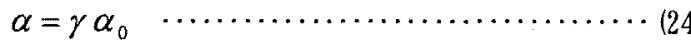

$$
\begin{aligned}
& \gamma=\frac{W_{I}}{W_{I 0}}=\frac{T_{1} \omega}{T_{I 0} \omega_{0}}
\end{aligned}
$$

添字 0 は，基準状態における値を意味する。一方 $\beta$ は， (19) 式から以下のようにして計算式が誘導される。

$$
\begin{aligned}
& T=k_{a} k_{M C} \sqrt{W} \ldots \ldots \ldots \ldots \ldots \ldots \ldots \\
& T_{I}=\gamma \frac{\omega_{0}}{\omega} T_{I 0}=\gamma \frac{\omega_{0}}{\omega} \beta_{0} k_{a 0} k_{M C 0} \sqrt{W} \\
& \beta=\frac{T_{I}}{T}=\frac{\gamma \omega_{0} k_{a 0} k_{M C 0}}{\omega k_{a} k_{M C}} \beta_{0} \equiv \frac{\lambda}{k_{a}} \beta_{0}
\end{aligned}
$$

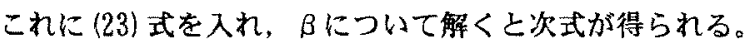

$$
\begin{gathered}
\beta=\frac{\lambda \beta_{0}}{\sqrt{1-\alpha}-\lambda \beta_{0}} \\
\lambda=\frac{\gamma \omega_{0} k_{a 0} k_{M C 0}}{\omega k_{M C}}
\end{gathered}
$$

なお, 効率 $\eta$ は $\alpha$ と $\beta$ 用いて次式のように表される。

$$
\eta=\frac{\omega T}{\omega T+\omega T_{I}+W_{C}}=\frac{\alpha}{\alpha+\beta}
$$

\section{4. 非ラップ集中巻永久磁石モータへの適用}

小形モ一夕設計の実際では，外形寸法が与えられてその 中で最大の出力を得る構造を見いだすことが重要である。 ここでは，小形ブラシレスモータに適する非ラップ集中巻 構造について，磁石性能に対する依存度の大きい空隙磁束 密度を基準にして鉄心構造と出力評価指標との関係を計算 し，最適設計問題へのアプローチを試みる。
図 2 に代表的な非ラップ集中巻永久磁石モータの構造を 示す。ここでは，文献 (1) と同じ (a)の構造を対象にして, 寸法変更に伴う評価指標の変化を前章の手法で計算する。

図 3 は，鉄心菌磁束密度をパラメータにして空腺磁束密 度と回転子外径を変化させ， $k_{M}$ の最大值とそれに対応する 諸元を求めるプログラムの概略構成である。銅損評価によ る $k_{\mathrm{MC}}$ の計算と，それに鉄損を考慮して求めた修正係数 $k_{a}$ を乗じて評価指標 $k_{M}$ を計算している。

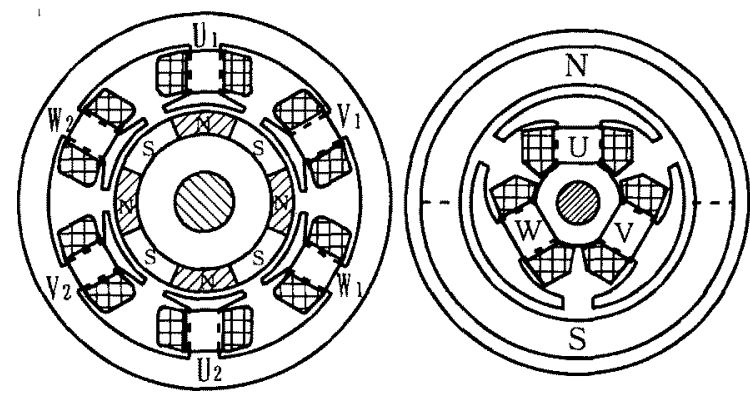

(a) Inner Magnet Type

(b) Outer Magnet Type 図 2 非ラップ集中巻多相巻線

Fig. 2. Non-Lap Concentrated Polyphase Windings

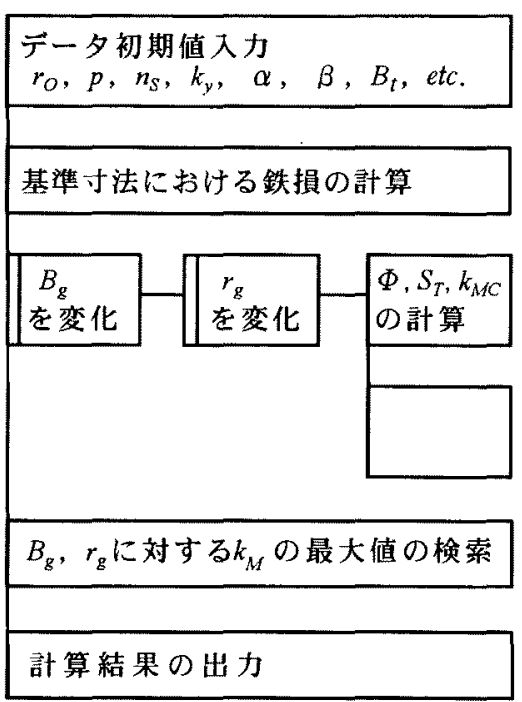

図 $3 k_{M}$ の計算手順 (PAD)

Fig. 3. Calculation Procedure of $k_{M}(\mathrm{PAD})$

〈4. 1〉寸法变化に対する $k_{M C}$ の計算 対象とする非 ラップ集中巻永久磁石モータの寸法記号を図 4 に示す。簡 単のため，次の関係式が成立するものと仮定する。

$$
\begin{aligned}
& l_{y}=k_{y} t, \quad l_{b}=k_{b} t \\
& B_{y}=B_{t} / k_{y}, \quad B_{b}=B_{t} / k_{b}
\end{aligned}
$$

また極チッブ部分は，図の破線で示すように厚さが $l_{p}$ から スリット中央部で 0 となるような三角形状とし，磁束密度 は畨中央部と同じ $B_{t}$ 一定であると仮定する。 


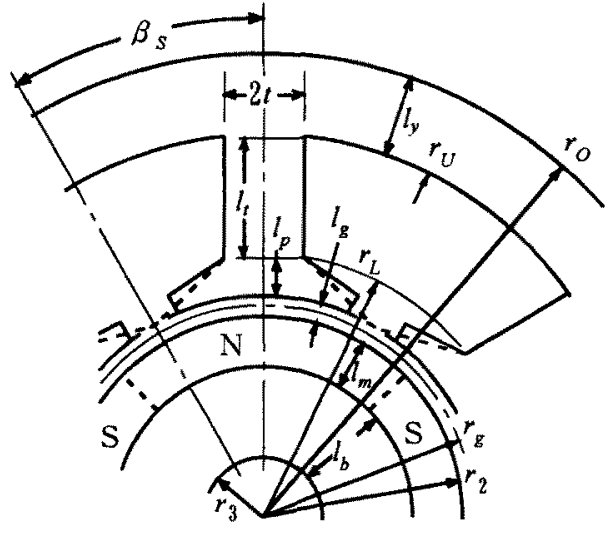

図4 非ラップ巻線モータのパラメータ

Fig. 4. Parameters of Non-Lap Winding Motor

さらに，計算に当たって以下の項目を仮定する。

(1) 鉄心歯部の最大磁束密度を任意の值 $B_{t}$ に固定する。

（2）空際磁束密度は，電気角度で正弦波状に分布する。

$$
B_{g}=B_{g m} \cos (p \theta)
$$

（3）鉄心の菊に入る磁束は，スリットを含めた角度 $2 \beta_{s}$ と積厚 $L$ の間の空際磁束密度の樍分值とする。

$$
\begin{aligned}
\Phi & =2 L \int_{0}^{\beta_{s}} B_{g m} \cos (p \theta) r_{g} d \theta \\
& =2 L r_{g} B_{g m} \sin \left(p \beta_{s}\right) / p
\end{aligned}
$$

仮定 (1)によって次式が成立する。

$$
t=\frac{\Phi}{2 L B_{t}}
$$

巻線スロットの総断面積は，图で $r_{U}$ と $r_{L}$ で囲まれたり ング帯から蒾部 $\left(2 t l_{t}\right)$ を差し引いた面積であるとする。

$$
S_{T}=\pi\left(r_{U}^{2}-r_{L}^{2}\right)-2 t l_{s} n_{s}
$$

$\Phi$ と $S_{T}$ を(7) 式に代入して $k_{M C}$ を計算することができる。 〈4.2〉鉄損を考慮した $k_{a}$ の計算 前章で述べたよう に，ここではある任意の基準条件において $\alpha$ とを設定し， 寸法変更によるそれらの変化から修正係数を計算する方法 を採用する。

図 5 に計算手順を示す。( )内は関係式の番号である。 ここでは，全許容損失を一定とし，かつ磁性材料内の最大 磁束密度をパラメータとして寸法を決めているので，鉄椇 の比が磁性材料の重量の比となり，このように比敕的简単 な手順になる。重缹は, 歯 $V$, とチップ $V_{p}$ おびヨーク部 $V_{y}$ に分けて次式で計算される。 $\delta$ は鉄心材料の密度である。

$$
\begin{aligned}
& V_{1}=2 t l_{t} L n_{s} \delta \\
& V_{p}=\left\{\left[\left(r_{g}+l_{g}\right) \pi / n_{s}-t\right]+2 t\right\} l_{p} \operatorname{Ln}_{s} \delta \\
& V_{y}=\pi\left(r_{o}^{2}-r_{U}^{2}\right) L \delta
\end{aligned}
$$

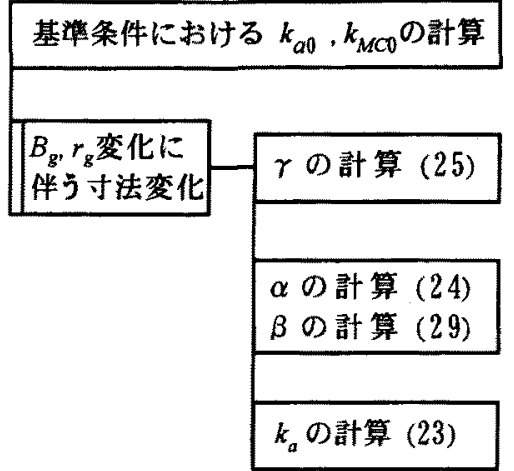

《 $5 k_{a}$ の計算手順 (PAD)

Fig. 5. Calculation Procedure of $k_{a}(\mathrm{PAD})$

\section{5. 評価指標の計算結果}

以上の手法を, 文献 (1) と同じ寸法の構造に適用して計 算を試みる。鉄損は，材料・構造等の条件によって大幅に

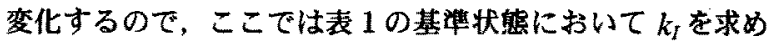
この値を固定して (12) 式で求める。表 1 では, 胃実のモ一 夕に則し $\tau \alpha=0.3 ， \beta=0.1$ とした。このとき，効率は (31) 式より $75 \%$ となり，この寸法のモータでは妥当な值 を示している。また, $k_{a}=0.76$ になるので, この場合の 発生し得るトルクは鉄損を考虑しない場合の $76 \%$ に低下 することになる。

以下に，鉄損を無視した場合と考慮した場合を対比させ ながら，永久磁石モータの設計において選択すべき各種パ ラメータの関係を調べこととるす。

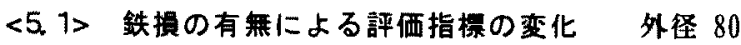
$\mathrm{mm}$, 鉄心積厚 $40 \mathrm{~mm}$ の永久磁石モー夕について，鉄䪱を 考慮した場合と無視した場合の計算結果を図 6 〜図8に示 す。鉄心歯の磁束密度を 1.4 Tとして, 空淂磁束密度と磁 石外经を変化させた場合の計算結果を，それぞれ磁石外经 $40 \mathrm{~mm}$ と架陽磁束密度 0.5 Tの断面で示している。

図6では，空傹磁束密度を一定にして回転子磁石の外经 を変化させた場合の評価指標の他に，巻線スロットの総断 面積 $S_{T}$ とコイル磁束Фの値をあわせて示した。ロー夕外经 の增加とともに， $S_{T}$ が减少しФが増加するので，評価指標 には最大点が存在する。図6より，鉄損を考慮した場合の 評価指標 $k_{M}$ は，当然ながら無視した場合の指標 $k_{M C}$ より小 さくなるが，それらが最大になる磁石外径はほほ一致し，

\section{表 1 鉄損算定の基準条件}

Table 1. Standard Condition for Iron Loss Estimation

\begin{tabular}{c|c||c|c||c|c}
\hline 項 & 値 & 項 & 値 & 項目 & 值 \\
\hline 目 & 4 & 目 & 6.5 & $2 r_{2}{ }^{*}$ & 40 \\
\hline $2 p$ & 6 & $2 t^{*}$ & 1.2 & $f_{s}$ & 0.3 \\
\hline$n_{s}$ & 80 & $k_{y}{ }^{*}$ & 0.7 & $\alpha$ & 0.3 \\
\hline $2 r_{o}^{*}$ & 40 & $k_{p}{ }^{*}$ & 1.4 & $\beta$ & 0.1 \\
\hline \multicolumn{7}{c}{ 単位 $: \mathrm{mm})$}
\end{tabular}




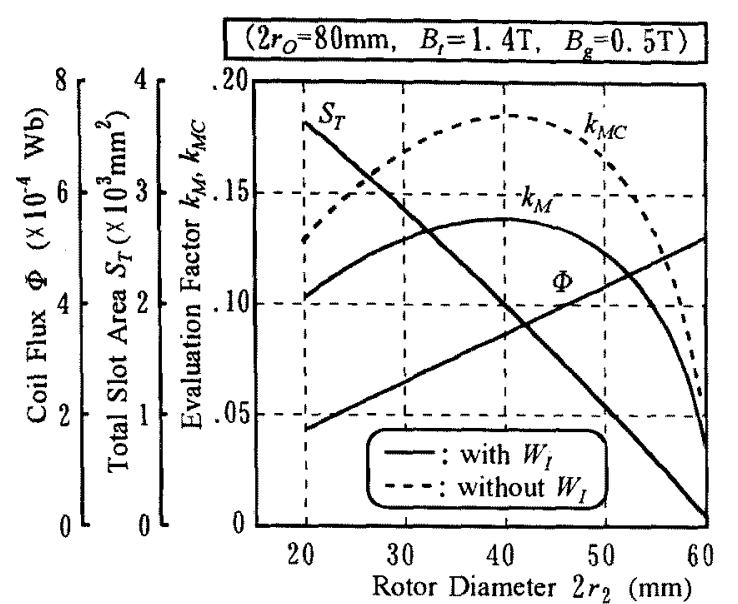

図6 $r_{2}$ に対する $\Phi, S_{T}, k_{M}$ の変化

Fig. 6. Variation of $\Phi, S_{T}, k_{M}$ with $r_{2}$

\section{鉄心外经の約 2 分の 1 になっている。}

図 7 は, 磁石外径を上記の最大值 $40 \mathrm{~mm}$ にして空陣磁 束密度 (実際問題としては磁石の磁束密度) を変化させた 場合である。鉄損を考慮した場合の評価指標は，鉄損を考 慮しない場合の $B_{g m}(0.9 \mathrm{~T})$ よりも小さい $B_{g m}(0.7 \mathrm{~T})$ で最大になっている。高磁束密度では鉄損が增加するので, 当然の結果であるが, 数值的に捉えられる点が本評価法の 利点である。

图 8 は, 空際磁束密度に対して得られる最大の評価指標 とそれに対応する磁石外佳と鉄心歯幅を示した。鉄損を無 視した場合にも空嘹磁束密度とともに評価指標が飽和する 傾向がみられるが，鉄損を考虑した場合はさらに顥著にな り，このケースでは $B_{g m}$ が 0.7 Tを越すとほとんど評価指 標の增加がなくなり，したがって出力增加も望めない状況 である。これは，鉄損の小さい鉄心材料の採用によって緩 和されると思われるが，設計上注目すへきき点と思われる。

図 9 に，この場合の鉄損の割合 $\alpha$ と修正保数 $k_{a}$ の変化の 様子を示した。 $B_{g m}$ の增加に伴って，鉄心の体積が増加す るので,鉄損が增加して $k_{a}$ もほ活直線的に減少する。また $k_{a}$ の低下によって発生トルクも減少するため， $B_{g m}$ の大きい ところでは $\beta$ 増加が加速する様子が見られる。

〈52〉歯磁束密度变化と評価指摽同一鉄心材料を 想定して，鉄心迷の磁束密度をパラメータにした場合の図 8 に相当する評価指標の計算值を図 10 に示す。図には, 比较のため図 8 の值も再揭した。いずれの場合も, 空吵磁 束密度が 0.7 T以上になると評価指標の増大が難しいこと が分かる。また, 歯磁束密度が 1.8 Tのように大きくなる と, 評価指標が 0.8 Tをピークに低下するので逆効果であ る。これらの数值は材料や構造にも依存するが，鉄損の割 合が大きい場合には十分注意を要する問題である。

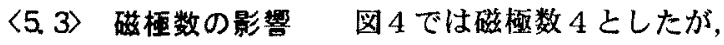
このモータは図2 (a)のように8極でも動作する。そこで, 8 極の場合について同じ計算を行った結果が図 11 である。 図では，空隚磁束密度 0.7 丁あたりが最大になり，それ以

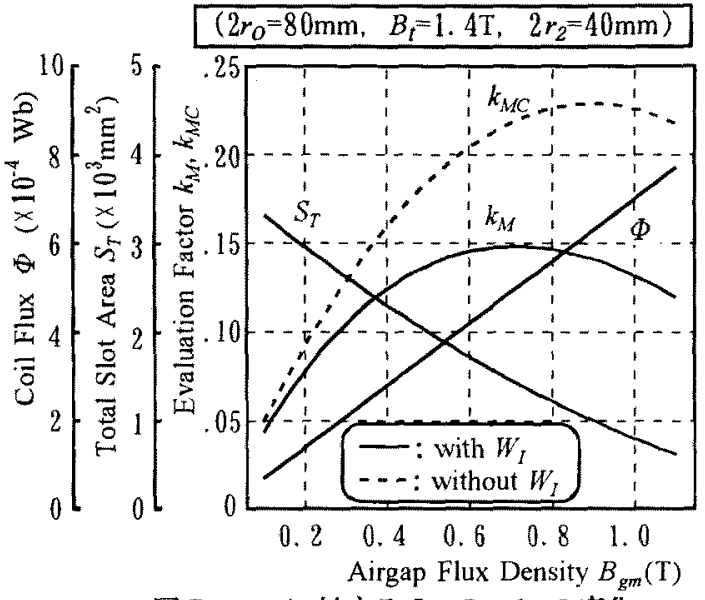

図 $7 B_{g m}$ に対する $\Phi, S_{T}, k_{M}$ の変化

Fig. 7. Variation of $\Phi, S_{T}, k_{M}$ with $B_{g m}$

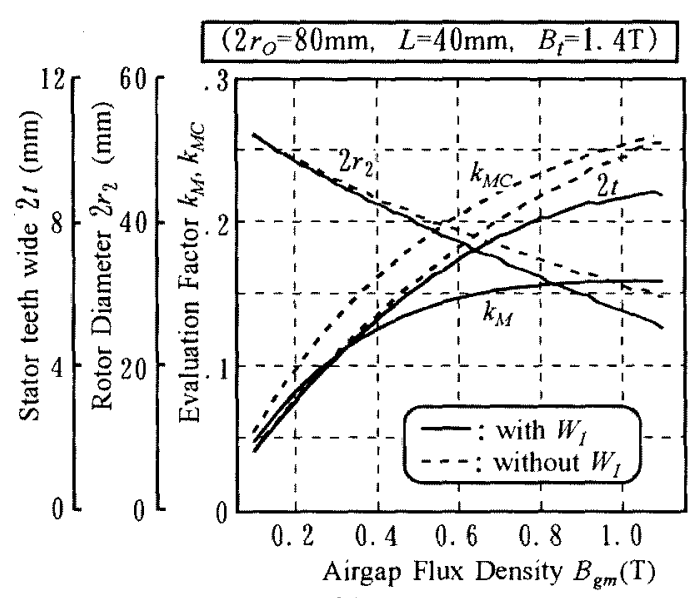

図 8 非ラップ巻線モータの最適設計

Fig. 8. Optimum Design of Non-Lap Winding Motor

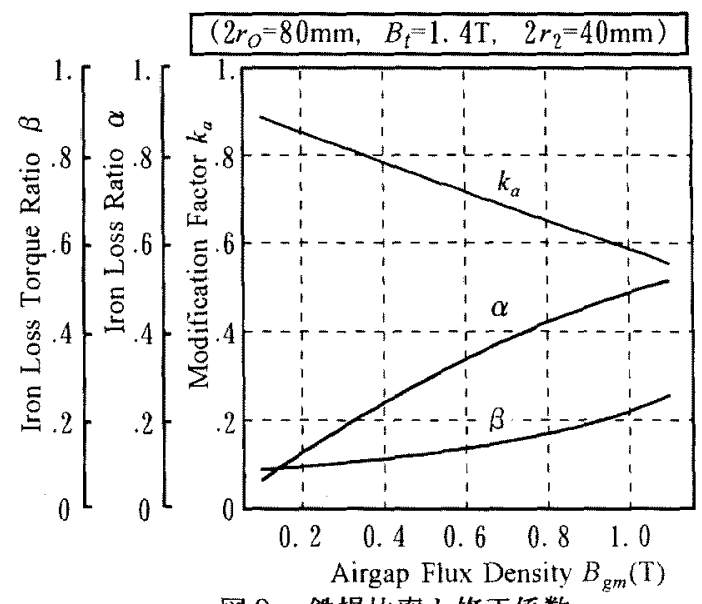

因 9 鉄損比率と修正係数

Fig. 9. Iron Loss Ratio and Modification Factor

上では磁束增加は逆効果になっている。同一回転数では周 波数が 2 倍になり，鉄損增加をもたらすためと考えられる。 


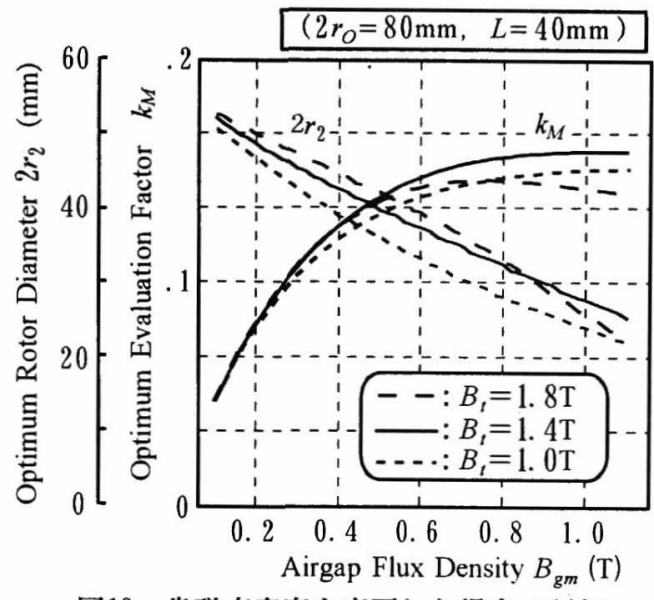

図10 歯磁束密度を変更した場合の評価

Fig. 10. Evaluation on Teeth Flux Density change

〈5. 4〉回転速度の影幚 ロー夕外径を $40 \mathrm{~mm}$ 一定と して回転速度比を 0.5 から 2.0 まで変化して図 7 に相当す る計算から, $k_{M}$ の最大值とそのときの $B_{g m}$ を読んで, その 変化を描くと図 12 のようになる。速度が高くなるほど $k_{M}$ が減少し, それを得るために $B_{g m}$ を減少させる必要のある ことがわかる。

以上の計算結果において最適な空隙磁束密度が $0.7 \mathrm{~T}$ 程 度と低めになるのは, 鉄心の磁気飽和の存在と高磁束密度 での鉄損増加が最大の原因であると考えることができる。

\section{6. まとめ}

主要な小形モー夕の母体である永久磁石同期モー夕につ いて，先に導いた銅損のみを考慮したトルク評価指標の考 え方を拡張し，鉄損の影響を考慮できる新しい評価指標を 導出した。これは, 銅損のみで計算した指標 $k_{M C}$ に鉄損分 の修正係数 $k_{a}$ を計算して乗ずるという比較的シンプルな形 になる。

つぎに，この新評価指標の計算法を以前の方法と対比さ せながら, 小形ブラシレスモータに多用されている非ラッ プ集中巻線形構造を対象にして適用を試みた。

計算の結果，鉄損を無視した場合に比べて，磁束量およ び磁束密度を上げることによる評価指標（すなわち出力ト ルク）向上の効果が低減されることがわかった。またこの 結果, 永久磁石材料については, 集中巻構造の場合空隙磁 束密度で $0.7 \mathrm{~T}$ 程度までの性能で十分であると思われる。

今後は, さらに細かい検討を進め, モータの省エネル ギー化のため基礎技術を整備して行きたい。

(平成 10 年 6 月 15 日受付, 平成 10 年 10 月 29 日再受付)

\section{文 献}

(1) 大西 : 「永久磁石モータのトルク評価と最適構造の検 討」, 電学論 D, 115-D, $930 \sim 935$ (1995-7)

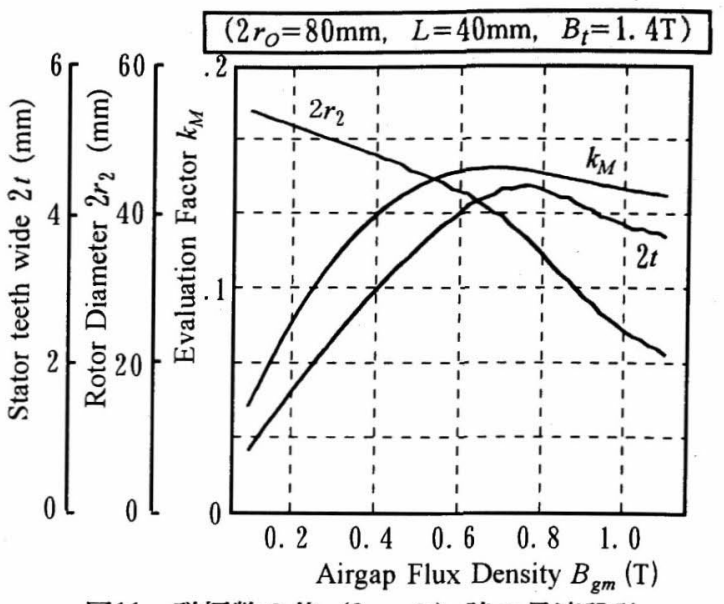

図11 磁極数 2 倍 $(2 p=8)$ 時の最適設計

Fig. 11. Optimum Design on Doubled Pole-Number

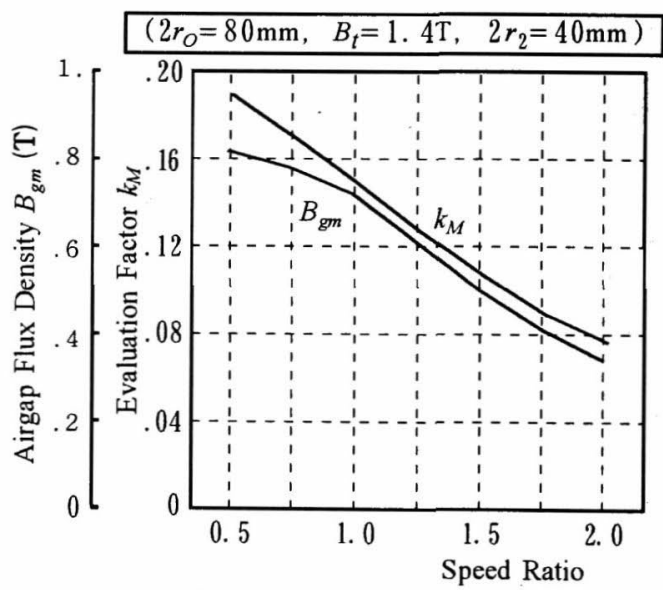

図12 速度に対する $k_{M}, B_{g m}$ の変化

Fig. 12. Variation of $k_{M}, B_{g m}$ with Speed Change

（2）リヒター(一木他訳）：「電気機械原論」，コロナ社, (1977)

(3) 開道, 脇坂 : 「無方向性電磁鋼板の鉄損に及ほす素材要 因の影響」, 電学論 A, 117-A，685～690 (1997-7)

(4) 大西 :「銅損と鉄損を考慮した集中巻永久磁石モー夕の 出力評価」, 電気学会回転機研究会資料, RM97-153 (1997)

大西 和夫

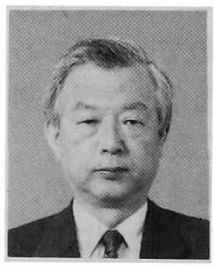

（正員）58 年 3 月京都大学工学部電気工 学科卒業。同年 (株) 日立製作所入社。日 立研究所および本社等で回転機とパワー エレクトロニクス関係の研究開発担当。 1985 年に日本サーボ (株)に移り, 現在同 社常務取締役研究所長。小形モー夕およ び同応用製品の開発を担当。 